кандидат юридических наук, доцент, доцент кафедры прокурорской деятельности Уральского государственного юридического университета

\section{ОЦЕНКА ПРОКУРОРОМ МАЛОЗНАЧИТЕЛЬНОСТИ ПРАВОНАРУШЕНИЯ ПРИ РЕШЕНИИ ВОПРОСА О ВОЗБУЖДЕНИИ ДЕЛА ОБ АДМИНИСТРАТИВНОМ ПРАВОНАРУШЕНИИ}

\begin{abstract}
Аннотация:
В статье исследованы вопросы использования су дами нормы о малозначительности административных правонарушений в деятельности прокурора, участвующего в рассмотрении административных дел, на примере судебной практики. Автор обращает внимание на проблему применения судами положений о малозначительности админи стративного правонарушения в деятельности прокурора. Сама возможность обращения к категории малозначительности при формальных составах административных правонарушений расценивается как ошибочная, нарушающая порядок привлечения к ответственности. Предлагается законодательно установить критерии малозначительности, исходя из уровней административных наказаний, предусмотренных в санкции статьи, а также предоставить прокурору полномочия рассматривать вопросы малозначительности правонарушения при возбуждении административного производства. В работе затрагиваются практические моменты доказывания прокурором в суде состава административного правонарушения. Автор делает выводы по результатам обобщения судебной практики.
\end{abstract}

Ключевые слова:

прокуратура, прокурор, административные правонарушения, малозначительность правонарушения, административная ответственность.
PhD in Law Associate Professor, Prosecutorial Activities Department, Ural State Law University

THE EVALUATION OF MINOR OFFENSES

BY THE PROSECUTOR WHEN INITIATING ADMINISTRATIVE PROCEEDINGS

Summary:

The research focuses on the problems of applying the rule and provision of minor offenses by courts and analyzes the case law and prosecutor's participation in administrative procedure. It is wrong to apply the category of minor offenses in the context of formal elements of administrative offenses as it violates the order of prosecution. It is proposed to establish the legislative criteria for minor offenses due to the level of administrative penalty stipulated in the relevant article and empower the prosecutor to deal with minor offenses when initiating administrative procedure. The study considers the practical issues of proving the elements of an administrative offense by the prosecutor in court. The author summarizes the results of the case law analysis.

Keywords prosecutor's office, prosecutor, administrative offenses, minor offense, administrative responsibility.

В соответствии со ст. 2.9 Кодекса Российской Федерации об административных правонарушений (далее - КоАП РФ) при малозначительности совершенного административного правонарушения судья, орган, должностное лицо, уполномоченные решить дело об административном правонарушении, могут освободить лицо, его совершившее, от административной ответственности и ограничиться устным замечанием [1]. В каждом конкретном случае суд сам с учетом обстоятельств совершения правонарушения должен квалифицировать правонарушение, при этом его квалификация как малозначительного может иметь место только в исключительных случаях и обусловливаться обстоятельствами совершенного лицом деяния. Правоприменительная практика освобождения лица от административной ответственности в связи с малозначительностью далеко не однозначна, а законодательство нуждается в дополнительном регулировании.

В таком случае роль прокурора, участвующего в рассмотрении дел об административных правонарушениях судами или должностными лицами, уполномоченными на это, незавидна. С одной стороны, участие прокурора в суде и поддержание вынесенного им постановления о возбуждении дела об административном правонарушении являются продолжением надзорной деятельности прокуратуры и соблюдения принципа неотвратимости наказания. С другой стороны, прокурор оказывается в ситуации, когда он затрачивает силы на проведение проверки, сбор и надлежащую фриксацию доказательств состава административного правонарушения, при этом судья или 
должностное лицо своим постановлением освобождают виновное лицо от административной ответственности и делают замечание. Положение усугубляет также фракт, что прокурор не может опротестовать вынесенное постановление о привлечении к административной ответственности или судебное решение по мотиву неверной оценки судом критериев малозначительности.

1. Проблема применения нормы о малозначительности. Одной из главных проблем законодательного регулирования оснований освобождения от административной ответственности является отсутствие в КоАП РФ понятия «малозначительность», а также оснований для оценки административного правонарушения как малозначительного. Интерпретационными актами высших судебных инстанций выработаны ключевые критерии, которые могут быть положены в основу малозначительности. Однако ввиду того что дела об административных правонарушений рассматриваются в соответствии как с КоАП РФ, так и с АПК РФ, указанные критерии различаются, что также выступает самостоятельной сложностью правоприменения [2].

Так, постановлением Пленума ВАС РФ от 02.06.2004 г. № 10 «О некоторых вопросах, возникших в судебной практике при рассмотрении дел об административных правонарушениях» определяющим фрактором установлено отсутствие существенной угрозы охраняемым общественным отношениям [3]. Кроме того, в указанном документе предусмотрены критерии, которые не могут быть положены в основу оценки правонарушения как малозначительного, поскольку должны быть учтены при назначении административного наказания. Не являются обстоятельствами, квалифицируемыми как малозначительные, личность и имущественное положение привлекаемого к ответственности лица, добровольное устранение последствий правонарушения, а также возмещение причиненного ущерба. Однако последние не следует путать с ролью правонарушителя, а также с размером и тяжестью последствий правонарушения, которые зачастую трактуются арбитражными судами как критерии малозначительности.

Кроме того, решением Арбитражного суда Свердловской области от 20.06.2017 г. по делу № А60-19195/2017 производство по заявлению заместителя прокурора Ленинского района города Нижний Тагил Свердловской области о привлечении к административной ответственности С. за совершение административного правонарушения, предусмотренного в ч. 4 ст. 14.13 КоАП РФ - незаконное воспрепятствование деятельности арбитражного управляющего, конкурсного управляющего либо временной администрации кредитной или иной фринансовой организации, было прекращено ввиду малозначительности правонарушения. В мотивировочной части суд указал, что правонарушение при формальном наличии всех признаков соответствующего состава само по себе не содержит какой-либо опасной угрозы охраняемым общественным отношениям, не причинило существенного вреда интересам граждан, общества и государства, права кредиторов, должника при проведении процедуры конкурсного производства не нарушены, последствия нарушения не носят неустранимого характера.

Иначе оценивается малозначительность административного правонарушения судами общей юрисдикции и должностными лицами. Постановлением Пленума Верховного суда РФ от 24.05.2005 г. № 5 «О некоторых вопросах, возникающих у судов при применении Кодекса Российской Федерации об административных правонарушениях» малозначительным признается правонарушение, которое с учетом характера совершенного деяния и роли правонарушителя, размера вреда и тяжести наступивших последствий не представляет существенной опасности для охраняемых общественных отношений [4]. Таким образом, Верховный суд РФ значительно расширяет критерии для применения судами общей юрисдикции нормы ст. 2.9 КоАП РФ, принимая во внимание также роль правонарушителя, размер вреда и тяжесть последствий, которые Высшим арбитражным судом РФ отнесены к смягчающим или отягчающим обстоятельствам и учитываются уже при назначении наказания.

Неоднозначность и отсутствие единообразия в применении судами положений о малозначительности административного правонарушения дополняются невозможностью оценивать условия и основания вынесения решения о малозначительности в ходе кассационного пересмотра дела в системе арбитражных судов, а также переоценивать выводы должностного лица или судьи, если последние не связаны с существенными нарушениями процессуальных норм, в соответствии с п. 4 ч. 1 ст. 30.7 КоАП РФ. В связи с этим при пересмотре постановлений о привлечении к административной ответственности вышестоящий суд не может повторно оценить условия применения нижестоящим судом статьи 2.9 КоАП РФ в конкретном деле и дать новую оценку угрозы охраняемым общественным отношениям. Поэтому нередко возникает ситуация, когда суд первой инстанции или должностное лицо, уполномоченное рассматривать дело об административном нарушении, по итогам рассмотрения постановления прокурора о возбуждении административного производства вынесли постановления о прекращении дела за малозначительностью правонарушения, а отсутствие существенного нарушения процессуальных норм при вынесении постановления не позволяют судам отменить указанное постановление при его пересмотре по протестам прокуроров, так как переоценка выводов суда или должностного лица о малозначительности невозможна. 
Отдельного внимания заслуживает вопрос о полномочиях прокурора в ходе надзорной деятельности оценивать возможность применения судами статьи 2.9 КоАП РФ и в некоторых случаях отказываться от вынесения постановления о возбуждении дела об административном правонарушении. Ответ на него однозначен и не раз был предметом толкования суда. Освобождение виновного лица от административной ответственности является прерогативой суда или органа, уполномоченного на разрешение дела об административном правонарушении.

Между тем полагаем данные изменения целесообразными. Предоставление прокурору права оценивать на стадии возбуждения административного производства малозначительность деяния позволило бы ориентировать его на привлечение к ответственности за правонарушения, посягающие на общественно опасные отношения. Прокурор мог бы самостоятельно на этапе возбуждения административного производства отсеивать очевидно малозначительные правонарушения, избегая тем самым возбуждения безосновательного производства по делу [5]. В этом случае прекращение впоследствии судом производства по делу об административном производстве ввиду малозначительности можно было бы оценивать как брак в работе прокурора, неправильно оценившего общественную опасность совершенного правонарушения.

Однако для реализации данного нововведения недостаточно изменения самой нормы ст. 2.9 КоАП РФ, требуется в первую очередь отойти от дискреции суда по применению оценочного понятия малозначительности, а также установить ее четкие критерии. Полагаем, что оптимальным решением проблемы малозначительности административных правонарушений было бы использование данной категории не во взаимосвязи с угрозой охраняемым общественным отношениям, а в соответствии с «лестницей административных наказаний». Считаем правильной позицию А.Б. Панова, говорящего о необходимости законодательного определения тяжести каждой меры ответственности согласно «лестнице наказаний» и законодательном регулировании возможности прекращения административных производств ввиду малозначительности только в отношении тех составов административных правонарушений, которые предусматривают определенные виды наказаний [6]. Указанное исключило бы применение нормы о малозначительности к правонарушениям, за которые предусмотрены такие наказания, как административный арест, административное выдворение, дисквалификация, административное приостановление деятельности. Кроме того, подобные поправки позволили бы прокурору при выявлении состава административного правонарушения самостоятельно предварительно оценивать возможность использования судами категории малозначительности при рассмотрении дела о привлечении к административной ответственности и, как следствие, допустили бы возможность отказа прокурора от вынесения постановления об административном правонарушении.

2. Повышение эффективности участия прокурора в рассмотрении судами дел об административных правонарушениях. В отсутствие каких-либо законодательных изменений в оценке малозначительности перед прокурором стоит ежедневная задача содействия суду в привлечении виновных к административной ответственности на основании вынесенных им постановлений. В связи с этим в целях анализа темы повышения эффеективности участия прокурора в рассмотрении судами и иными органами дел об административных правонарушениях и, как следствие, профилактики прекращения данными органами производств по делам ввиду малозначительности правонарушения следует остановиться подробнее на сборе прокурором доказательств совершения административного противоправного деяния.

Постановлением от 23.07.2018 г. № 17АП-8542/2018-АК Семнадцатый арбитражный суд в ходе пересмотра дела № А60-13675/2018 об административном правонарушении К. об отчуждении имущества, совершенного при наличии признаков банкротства гражданина (ч. 1 ст. 14.13 КоАП РФ), отказал в удовлетворении апелляционной жалобы, так как признал правонарушение малозначительным, мотивировав данный вывод тем, что не доказан факт существенной угрозы охраняемым общественным отношениям [7].

В другом случае Арбитражным судом Свердловской области 20.06.2017 г. по делу № 6019195/2017 были самостоятельно оценены фракты отсутствия доказательств причинения реального ущерба в результате совершения нарушений, в связи с чем суд также признал административное правонарушение, выраженное в незаконном воспрепятствовании С. деятельности конкурсного управляющего, в том числе несвоевременном предоставлении, уклонении или отказе от передачи конкурсному управляющему сведений и (или) документов, необходимых для исполнения возложенных на него обязанностей (ч. 4 ст. 14.13 КоАП РФ), малозначительным. Данное решение мотивировано тем, что при формальном наличии всех признаков соответствующего состава правонарушение не содержит какой-либо опасной угрозы охраняемым общественным отношениям, не причинило существенного вреда интересам граждан, общества и государства, права кредиторов, должника при проведении процедуры конкурсного производства не нарушены, последствия нарушения не носят неустранимого характера [8]. 
Поскольку в законе нет толкования понятия «существенная угроза охраняемым общественным отношениям», то суд связывает эту категорию с объектом посягательства в административном правонарушении. Так, в постановлении Семнадцатого арбитражного апелляционного суда от 21.03.2013 г. № 17АП-2099/2013-АК по делу № А50-23992/2012 существенной угрозой для общественных отношений послужили нарушения в сфере оказания услуг, выразившиеся в необорудовании входа (выхода) в помещение медицинского центра для людей с нарушениями функций опорно-двигательного аппарата, существенно ограничивающие права маломобильных групп [9].

Из мотивировок малозначительности административных правонарушений, данных судами, следует, что прокурор должен был доказать причинение реального ущерба иным лицам. Согласно ст. 26.1 КоАП РФ среди прочего выяснению подлежат характер и размер ущерба, причиненного административным правонарушением. Поэтому обязанность по определению ущерба лежит не только на суде или органе административной юрисдикции, рассматривающих дело, но и на должностном лице, составившем протокол, а также на прокуроре, вынесшем постановление о возбуждении дела об административном производстве [10]. В связи с этим представляется необходимым при вынесении прокурором постановления о возбуждении производства об административном правонарушении совершать необходимые действия по фиксации последствий причинения правонарушением ущерба иным лицам (объяснения потерпевших от правонарушения, справки о размере ущерба и т. п.) в целях последующего приобщения к материалам дела в качестве доказательств.

Особенностью использования судами критерия малозначительности административно-деликтных деяний является применение последствий этих деяний и к формальным составам административных правонарушений, которые в свою очередь превалируют в КоАП РФ. Так, несмотря на то что в формальных составах последствия деяния не имеют квалифицирующего значения, суды принимают их во внимание при выборе меры ответственности. В связи с этим следует заключить, что даже в формальных составах административных правонарушений прокурор должен самостоятельно оценить и доказать факт наступления реального ущерба или соответствующей угрозы, поскольку в этом случае судья может применить положения о малозначительности, а следовательно, оценить правонарушения на предмет причинения ущерба или угрозы его причинения. Таким образом, полагаем саму возможность применения категории малозначительности к формальным составам административных правонарушений ошибочной, нарушающей порядок привлечения к ответственности.

В заключение следует отметить, что повышение эффективности деятельности прокуратуры в форме усиления внимания к последствиям совершенных административных правонарушений следует расценивать как временный фрактор, используемый в отсутствие четкого законодательного закрепления критериев малозначительности и предоставления прокурору полномочий по оценке малозначительности правонарушения при решении вопроса о вынесении постановления о возбуждении административного производства по делу.

\section{Ссылки:}

1. Кодекс Российской Федерации об административных правонарушениях от 30 дек. 2001 г. № 195-Ф3 [Электронный ресурс] : в ред. от 28 нояб. 2018 г. Доступ из справ.-правовой системы «КонсультантПлюс».

2. Гуменюк Т.А. Малозначительность административного правонарушения как основание освобождения от административной ответственности // Вестник ВАС РФ. 2006. № 11. С. 16-29.

3. О некоторых вопросах, возникших в судебной практике при рассмотрении дел об административных правонарушениях [Электронный ресурс] : постановление Пленума ВАС РФ от 2 июня 2004 г. № 10 : в ред. от 21 дек. 2017 г. Доступ из справ.-правовой системы «КонсультантПлюс».

4. О некоторых вопросах, возникающих у судов при применении Кодекса Российской Федерации об административных правонарушениях : постановление Пленума Верховного суда РФ от 24 мая 2005 г. № 5 // Российская газета. 2005. 19 апр.

5. Винницкий А.В. Административная ответственность арбитражных управляющих: динамика и практика применения новых норм КоАП РФ // Административное и муниципальное право. 2017. № 12. С. 11-25.

6. Панов А.Б. О малозначительности административных правонарушений // Право. Журнал Высшей школы экономики. 2012. № 2. C. 80-98.

7. Постановление № 17АП-8542/2018-АК от 23 июля 2018 г. Семнадцатого Арбитражного суда по делу № А6013675/2018 [Электронный ресурс] // Право.ru : справочно-правовая система. 2018. URL: http://kad.arbitr.ru/PdfDocument/0fe9292e-e270-4f35-8cd2-35c360ff9b18/4b990b53-0124-4de4-85e2-908d02ee3c85/A60-13675-

201820180723 Reshenija i postanovlenija.pdf (дата обращения: 13.12.2018).

8. Решение Арбитражного суда Свердловской области по делу № A60-19195/2017 от 20 июня 2017 г. [Электронный ресурс] // Там же. 2017. URL: http://kad.arbitr.ru/PdfDocument/6d11e13f-4fd2-492a-b968-c9fd1b78d053/2cf4bdb1-8bf54fee-92ff-88c93ec28de8/A60-19195-2017_20170620 Reshenija i postanovlenija.pdf (дата обращения: 13.12.2018).

9. Постановление № 17АП-2099/2013-АК от 21 марта 2013 г. Семнадцатого Арбитражного суда по делу № А5023992/2012 [Электронный ресурс] // Там же. 2018. URL: http://kad.arbitr.ru/PdfDocument/f742e064-90fb-4dd1-be082e6ceb8e8b1c/1537954a-2d07-4430-9597-4e07b507142b/A50-23992-2012_20130321_Reshenija_i_postanovlenija.pdf (дата обращения: 13.12.2018).

10. Hill J., Chong A. International Commercial Disputes // Commercial Conflict of Laws in English Courts. Oxford, 2010. P. 4-5. 


\section{References:}

Gumenyuk, TA 2006, 'Minor Administrative Offense as a Basis for the Exemption from Administrative Responsibility', Vestnik VAS RF, no. 11, pp. 16-29, (in Russian).

Hill, J \& Chong, A 2010, 'International Commercial Disputes', Commercial Conflict of Laws in English Courts, Oxford, pp. 4-5.

Panov, AB 2012, 'Minor Administrative Offenses', Pravo. Zhurnal Vysshey shkoly ekonomiki, no. 2, pp. 80-98, (in Russian).

Vinnitskiy, AV 2017, 'Administrative Responsibility of Bankruptcy Commissioners: Dynamics and Practice of Application of the New Provisions of the Administrative Offences Code of the Russian Federation', Administrativnoye i munitsipal'noye parvo, no. 12, pp. 11-25. https://doi.org/10.7256/2454-0595.2017.12.24877. 